\title{
QUIET WRITING: RETREAT AS PEDAGOGY
}

\author{
M. Keane \\ Centre for Learning Teaching and Development (CLTD) \\ University of the Witwatersrand \\ Johannesburg, South Africa \\ e-mail: moyra.keane@wits.ac.za
}

\section{ABSTRACT}

In a climate of increased pressure on academics to publish, some writing retreats have become crash-courses on writing, or bootcamps for getting words on paper. I argue rather for a writing pedagogy that deliberately aims to restore a sense of well-being in writers, draws on creative writing (Haarhoff 1998) and is situated in a paradigm of mindful inquiry (Bentz and Shapiro 1998). Based on observations, reflections and evaluations of 18 retreats run over the past six years, for staff at a university in Johannesburg, I argue that the structure and process of the retreat is an integral part of the writing pedagogy. A retreat traditionally includes mindfulness, with a balance between effort and reflection. The writing retreat pedagogy I propose is a flow between being productive and restoring a sense of life-balance: quiet writing - meaning coming from a place of inner calm.

Keywords: writing retreat; mindful inquiry; wellness; creative writing; academic development

\section{INTRODUCTION}

Writing retreats have become a popular response to the increasing pressure on academics to publish: this is certainly the case at our research-intensive university in Johannesburg. Academic writing retreats have a number of different designs and purposes (Murray 2009) each of which attempts to navigate the tensions between having time to write and giving input on academic writing; between ensuring productivity and providing a conducive space for writing. The life of academics at universities is becoming more stressful and more pressured while life outside of work is similarly full of demands. Within this context academics endeavour to increase their publication rates, complete higher degrees and supervise larger numbers of students. The inevitable stress has a corrosive effect on well-being as well as productivity. Writing retreats have become a logical and prevalent response to provide time for writing and, in some cases, considerable instruction on the writing process. Writing retreats may also provide a time to reflect, recover and connect with fellow writers. These latter aspects are key in the writing retreat pedagogy I argue for: mindfulness and the use of mindful inquiry (Patton 2002). 
As facilitators of writing retreats at a university in Johannesburg over the past six years I, and my co-facilitators, have responded to observations, evaluations and free-writes of retreatants to refine a writing retreat structure and pedagogy that aims to address the current stressful context of academia while promoting creative thinking in research. I describe the key aspects of designing, facilitating and managing the retreat, recruiting writers, a typical programme, and report on outcomes. Retreats may provide balance between renewal and focus; freedom and commitment; autonomy and sharing; fun and accountability; right-brain and leftbrain activities (See Janks 2012). This need for balance arises particularly in the current Higher Education context of disruption and social change. As Lee $(2012,1)$ argues, even without this particularly stressful context, there are advantages of 'encourage[ing] fellow instructors not only to teach mindfulness but, more importantly, to teach mindfully'.

In this article I draw on evaluations of writing retreats that I have facilitated or cofacilitated, as well as observations and reflections of the facilitators, to ascertain what is valued by retreat participants, what structure, processes and pedagogies support writing. The retreats' qualitative responses to evaluations (including free-writes) were analysed thematically, and although the larger writing retreat research project obtained university ethics clearance, in this article, as I am presenting specific quotes, I do not give codes or dates as the retreat groups were small and anonymity could be compromised. I present representative comments to illustrate retreatants' experiences.

I also describe the retreat approach which draws on strategies of creative writing (Haarhoff 1998; Badenhorst 2007; Cameron 2006) and mindful inquiry (Bentz and Shapiro 1998; Patton 2002). The responses of retreatants suggest that the 'retreat' aspect of a writing retreat is an essential site of learning, productivity and the development of the writer. A retreat implies a time away from demands and distractions where outer quiet encourages inner reflection, as well as collegial connection (Ashwin 2015). An appropriate framework and tradition of a retreat space is reflection and mindfulness. Mindfulness is the ability to be present, aware of what we are doing, and not overly reactive or overwhelmed by what is going on around us. ${ }^{1}$

This latter state may be fostered by the place, ethos, collegiality and focus in a group on a retreat. Mindful inquiry provides a framework for ‘inner research’ (Fensham 2004) - a complementary aspect of intellectual inquiry. In acknowledging the prevalent context of stress, I also draw on the wellness quadrant of the iOpener institute (see Pryce-Jones 2010) to show how the retreat structure and pedagogy is designed to provide a flow between being productive and restoring a sense of well-being and confidence in writing. This aspect of increasing confidence in writing is key (Devlin and Radloff 2014). 
The following section outlines the facilitators' expectations and aims, as well as typical examples of writers' stated aims for participating in a retreat.

\section{THE WRITING RETREAT}

\section{Facilitators' expectations of participants}

Facilitators expect participants to be committed to the programme, to contribute, and to focus, while also having the freedom to choose their own approach to writing and other relevant activities during individual writing time.

\section{Facilitators' aims for the retreat}

Facilitators intend that the retreat provides a space for restoring life-balance and a sense of wellbeing; enhancing confidence and joy in writing; developing the writer's voice and identity; fostering a community of practice of writers; encouraging creative thinking; and enabling progress on writing projects.

\section{Retreatants' aims and expectations}

Retreatants, in their motivation to attend the retreat, and at the start of a retreat, list their expectations as: time to write; support for writing; refuge from daily demands; overcoming writer's-block; enjoyment of intellectual engagement; collegiality; focus; goal achievement; commitment; and participation. It is clear that there is a fair commonality of purpose between facilitators and retreatants. The retreat programmes are also frequently revised with retreatants' expressed needs in mind. (See also Castle and Keane 2016).

Table 1: Typical writing retreat programme

\begin{tabular}{|l|l|l|l|}
\hline Time & Activity I requirement & Purpose & Note \\
\hline $\begin{array}{l}\text { Pre-retreat } \\
\text { Requirement }\end{array}$ & $\begin{array}{l}\text { Completion of 7-day Research } \\
\text { Writing course }\end{array}$ & $\begin{array}{l}\text { To set up ways of working with } \\
\text { peers; to experiment with } \\
\text { numerous strategies for } \\
\text { research writing, including } \\
\text { creative activities. }\end{array}$ & $\begin{array}{l}\text { Such a requirement } \\
\text { means more time can be } \\
\text { given to actual writing on } \\
\text { retreat. }\end{array}$ \\
\hline Pre-retreat & $\begin{array}{l}\text { Application with Motivation. } \\
\text { Commitment to programme \& } \\
\text { time frames. }\end{array}$ & $\begin{array}{l}\text { To establish focus for } \\
\text { participants, elicit preparation; to } \\
\text { ensure commitment. }\end{array}$ & $\begin{array}{l}\text { This assists in pushing } \\
\text { writers into action. }\end{array}$ \\
\hline Daily programme & \multicolumn{3}{|l|}{} \\
\hline 7h30 & Breakfast & $\begin{array}{l}\text { Creative / fun activities to } \\
\text { overcome writer's block, fear of } \\
\text { writing and sharing, to shake-up } \\
\text { habitual approaches. }\end{array}$ & $\begin{array}{l}\text { Participants often offer } \\
\text { movementivity: drawing, }\end{array}$ \\
\hline 8h30 & $\begin{array}{l}\text { 'Writing an abstract'; } \\
\text { 'Constructing an argument'; etc }\end{array}$ \\
\hline 10h30 & Tea & $\begin{array}{l}\text { Establish good practices of } \\
\text { balancing 'recovery' and }\end{array}$ & 'Restoring' \\
\hline
\end{tabular}




\begin{tabular}{|l|l|l|l|}
\hline Time & Activity / requirement & Purpose & Note \\
\hline $11 \mathrm{h00}$ & & 'productivity'. & \\
\hline $1 \mathrm{pm}$ & Individual writing time & $\begin{array}{l}\text { Developing sustained focus. } \\
\text { Having time to write. } \\
\text { Developing mindful inquiry. }\end{array}$ & $\begin{array}{l}\text { 'Writing is learned by } \\
\text { writing' Badenhorst, } \\
2007\end{array}$ \\
\hline $2 \mathrm{pm}$ & Lunch & $\begin{array}{l}\text { Community sharing. } \\
\text { Participants decide what they } \\
\text { need to do: walk, rest, discuss, } \\
\text { and write. }\end{array}$ & $\begin{array}{l}\text { Facilitators available for } \\
\text { consultation. }\end{array}$ \\
\hline $4 \mathrm{pm}$ & Individual writing time & $\begin{array}{l}\text { Encouraging accountability, } \\
\text { providing input, establishing } \\
\text { voice of the writer, } \\
\text { democratising the feedback } \\
\text { process, learning from each } \\
\text { other, sharing. Empathy; mindful } \\
\text { listening. }\end{array}$ & $\begin{array}{l}\text { Facilitators also often } \\
\text { read their own work; } \\
\text { become participants in } \\
\text { the Community of } \\
\text { Practice. }\end{array}$ \\
& $\begin{array}{l}\text { Reading the day's writing in } \\
\text { groups; providing peer }\end{array}$ & & \\
\hline $5 p m$ & feedback. & & \\
\hline Evening & Reading / writing time / rest. & & \\
\hline
\end{tabular}

Retreat numbers are usually limited to 10 participants. Writers are welcome to participate in subsequent retreats as our experience confirms the findings of Moore, Murphy and Murray (2010) and Grant (2006) that participants particularly benefit from repeat retreats. Some seasoned retreatants have formed writing groups, arranged their own retreats or become facilitators of retreats. Facilitators also often engage with writers before the retreat to help them identify their writing project, and how they can use the retreat to develop their writer identity. The theoretical underpinnings of the retreat design and setting are mindfulness and mindful inquiry; creativity; and wellness.

\section{MINDFULNESS AND MINDFUL INQUIRY}

Mindfulness is knowing what it is happening while it is happening (Nairn 1999). This may seem absurdly obvious, even trite. Yet for most of us the experience of being fully present and not preoccupied with past hurts, future anxieties, random thoughts, and circling inner chatter is rare. Our capacity for attention is central to the learning process and there is a clearly established link between mindfulness and insight. The latter is an essential requirement for research.

... your awareness of and reflection on your world and the intellectual awareness and reflection that are woven into your research affect - or should affect - one another. Good research should contribute to your development as a mindful person, and your development as an aware and reflective individual should be embodied in your research. (Bentz and Shapiro 1998, 5).

The practice of mindfulness contributes to insight, productivity as well as physical stress reduction (see Nation Health Services in the UK, and the Oxford Mindfulness Centre. ${ }^{2}$

Aspects of stress for academic writers are the pressure to publish, but also the difficulty of the writing itself. Difficulties often lead to writer's block, a dilemma that can entrench a 
paralysing inertia. Kabat-Zinn makes a strong claim for mindfulness contributing to becoming unstuck:

Mindfulness provides a simple but powerful route for getting ourselves unstuck, back into touch with our own wisdom and vitality. (Kabat-Zinn 1994, 5)

While this is a clear benefit of mindfulness training, I suggest that it is not as easy as it sounds - hence the introduction of fun and creativity at the beginning of a retreat day. There is nothing like determination and high stakes to keep us brutally fixated on how well we are doing, and how much we are doing. I argue that a sense of fun assists us to gain perspective and relax. Easy creative activities at the start the of day are often the beginning of a new mental space where practicing letting go of thoughts about the past and future helps us develop focus and connect to others attentively.

\section{CREATIVITY IN THE CONTEXT OF ACADEMIC WRITING}

Rationality, intellect, and logic - the 'academic' - are reified, whilst imagination, emotion, and physical and natural rhythms - the 'creative’ are denigrated. (Antoniou and Moriarty 2008, 159).

It is apparent that some academics come to a retreat, or more usually, to the Research Writing course that is a prerequisite for attending a retreat, with attitudes similar to those described above. Most soon experience the benefits of what may at first appear to be trivial, childish or time-wasting activities and see how engaging the right side of the brain leads to change in perception and new knowledge. The joy of research is encapsulated in Goman's definition of creativity 'bringing into existence an idea that is new to you.' (Goman 1989, 2). Another aspect of creativity includes motivation (Palmer 2002) which is more healthily fostered through fun and thoughtful activities than through stressful external pressure. The retreat space can be designed to support the creative process by expecting challenge and involvement; low conflict levels; trust and openness; and risk taking, while providing a degree of freedom; idea time; humour and playfulness (Gundry 2007). Prather and Gundry $(1995,25)$ also identify the pitfalls to creativity as judging ideas too quickly; stopping the first good idea; failing to 'get the bandits off the train'; and obeying rules that do not exist. Palmer (2002) concurs with the latter stance to rules and adds that a creative way of relating to the world means possessing a deep empathy towards others.

The link of creativity to thought and hence academic research is obvious: De Bono (1995) describes creativity as a change in perception and concepts; and Mittens (2010, 7) writes: 'The 
creative process hinges on linking many ideas, perhaps previously unrelated. ... require[ing] an individual to think, write or speak in an agile manner.' Many of the definitions and conditions of creativity link to benefits of mindfulness and are features of the retreat design in that creativity cuts across habitual patterns of behaviour (Wheatley 2006).

Antoniou and Moriarty (2008) note that most academic scholarly writing interventions focus on technical and practical aspects, neglecting creative writing, which has much to contribute (Badenhorst 2007; Cameron 2006. Creative activities not only assist with the writing process but change the way we relate to our work and to each other. Through fostering an ability to be present and to play creatively we have an opportunity to see things anew. Kabat-Zinn expresses this distinction between thought, and being aware at a meta-level of the actual mental processes; of the possibility of new insights through allowing some habitual thinking to quieten.

It is something to be able to paint a particular picture, or to carve a statue ...; but it is far more glorious to carve and paint the very atmosphere and medium through which we look ... (Thoreau, quoted in Kabat-Zinn 1994, 183)

The quality of presence and clarity of seeing is what gives us the ability to write clearly and to have something original to say. As some of the seminal work above shows, there is a link between mindfulness, creativity and well-being. The development of mindfulness promotes well-being and the fostering of well-being is essential in the context of the academic life where stress has become so endemic that it is almost celebrated as an achievement.

\section{CONTEXT OF STRESS}

A wellness survey conducted at our university in Johannesburg in 2012 noted serious levels of stress among staff (CLTD 2012). That was before the current student protests, wide-ranging cost cutting measures, larger class sizes, freezing of new appointments, and proposals of performance management. Many academics would argue that stress is rife and university staff are close to burnout. Working from a place of burn-out or threat is obviously not conducive to long term quality of work. Researchers face the dilemma of needing to be productive while spinning into distress and demoralisation (Hanson 2009). On top of this is the additional pressure of research writing which 'is often experienced as destructive, mysterious, daunting and unsupported' (Moore, Murphy and Murray 2010, 21).

I use here a model of iOpener Institute to illustrate the futility of increasing pressure (and hence the stress) to make the production wheels turn faster. 


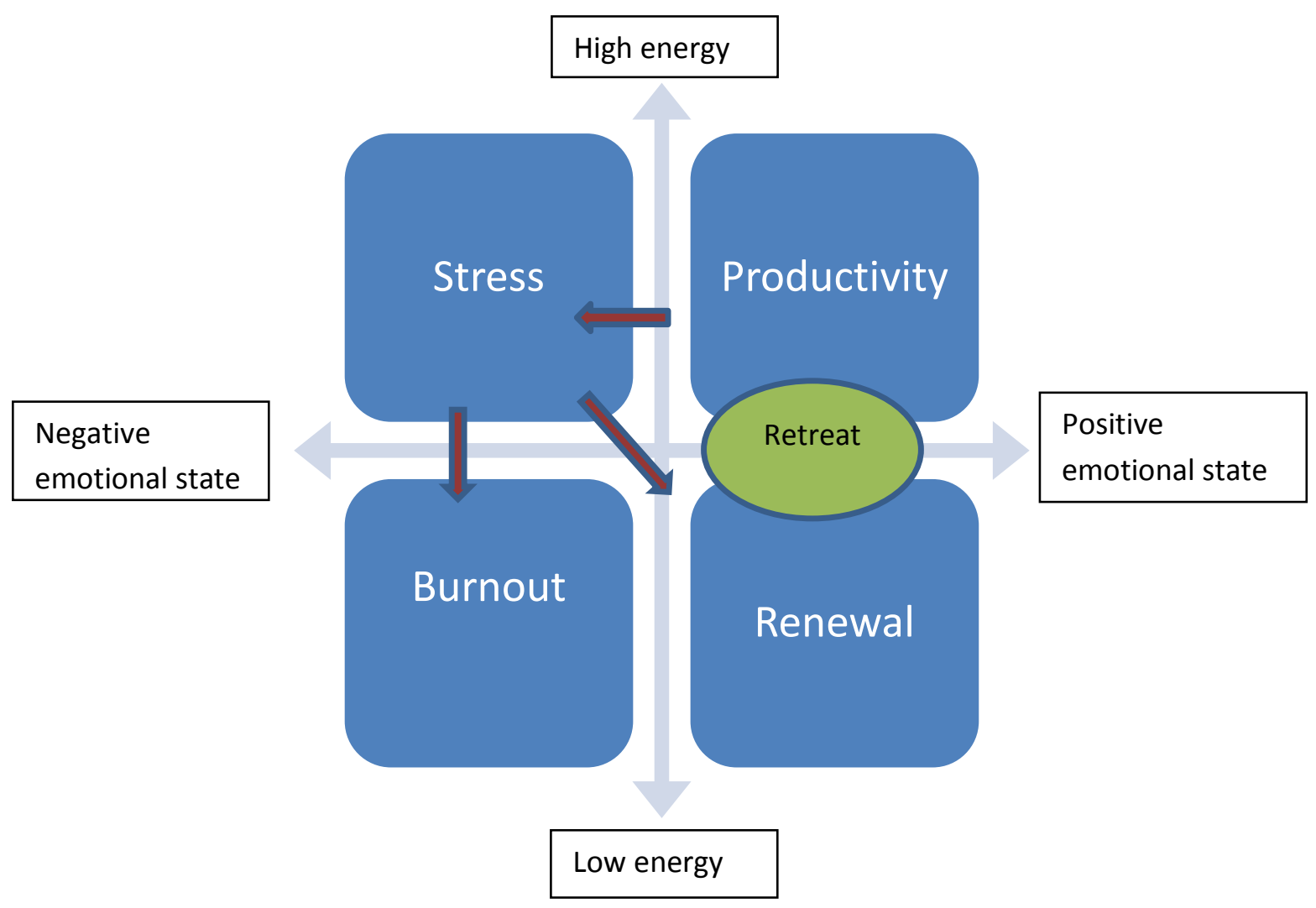

Figure 1: Wellness and stress quadrants (Adapted from IOpener Institute 2012)

Figure 1 illustrates how, if we start with a positive state and are productive we often over-work, come under increasing pressure, and move from 'Productivity' into 'Stress'; energy is still high as we frantically engage but our emotional state moves from positive to negative. Typically, we become less productive and less creative in this stressful state, thus falling behind and spiralling into more stress until we sink into a negative, low-energy state of 'Burnout'. The characteristics of each of the four quadrants are depicted in Figure 2.

Anyone functioning in the high energy levels of the upper right quadrant can easily move (as mentioned) from a positive frame to a negative frame (top left quadrant) where focus is lost to competing demands and actions display symptoms of stress and panic. Spending time in this state will lead to energy depletion and burnout (bottom left quadrant). This low energy state could linger until the individual moves again to Productivity, through Renewal (bottom right quadrant).

To avoid this negative cycle from productivity to stress to burnout, it is wise to move mindfully from Productivity to Renewal. This can happen on a micro time scale of taking periodic breaks during the day; by finding renewal in 'restoring' activities and taking time-out. 
The argument presented in this model is that in order to be productive with a positive high energy state, we need to find renewal in positive low energy states and activities. This balance between Productivity and Renewal is what I argue for in a retreat design.

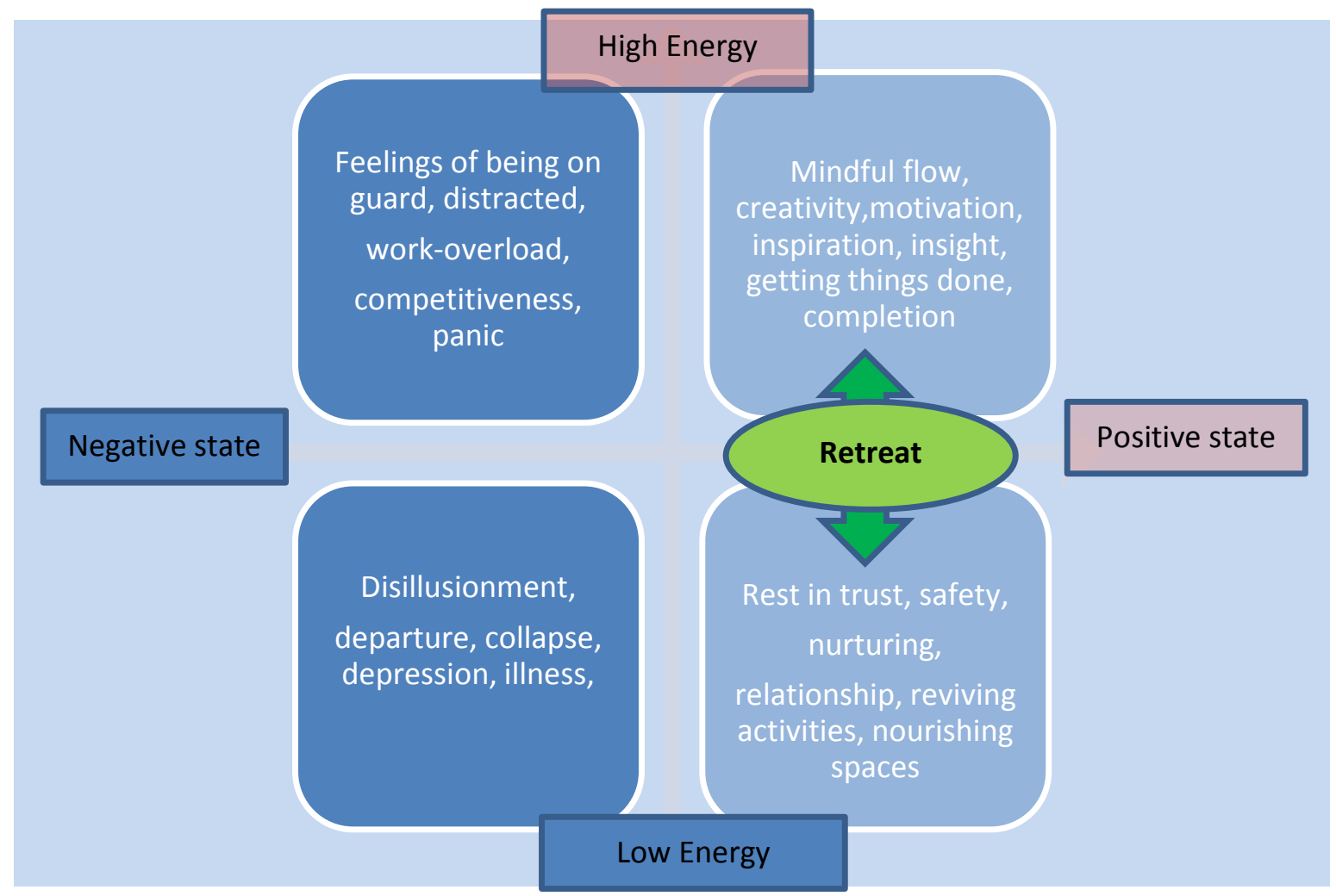

Figure 2: Characteristics of four quadrants of energy states

In this type of writing retreat restoring activities include creativity, walking in nature, good food and conversation, and rest. These relaxing aspects help writers destress so that they can move back to being productive, focussed and getting into the flow of writing. This approach is in line with the claim of Field, (2009, 40), 'Teaching approaches should actively seek to promote wellbeing'.

Conceiving the retreat as pedagogy means a cultivation of awareness of one's own needs and ways of working as well as contributing to the needs of the group. Through mindful engagement we can overcome unhelpful habits of thinking and working. Hence the retreat space is situated across Productivity and Renewal; this is a space where effort becomes effortless.

\section{THE CONCEPT OF RETREAT}

A retreat may mean a withdrawal from battle; a disengagement; an opportunity to change one's attitude or the conditions affecting us; a place to reconnect with what we value, with others; a 
space for recovery and profound learning. This learning typically dawns from periods of calm and reflection so that new insights may arise. In the Buddhist tradition, the practice of Samatha meditation develops calm and focus; Vipassana meditation allows for analysis of thoughts and fresh perspectives to emerge which may be transformative (See Samararatne 2007; Succito 2011). Both practices are necessary for letting go of habitual views and assumptions; developing sustained concentration; and discovering new insights.

There are similar transformational experiences in other traditions such as contemplative and solitary retreats in Islam and Christianity. The contemplative pedagogy is one which combines discipline with respite from busyness, so that the mind itself is cultivated. This is different from gaining more content knowledge and theoretical concepts. The nexus of Renewal and Productivity as presented in the Wellness Quadrant above is the fine attentive experience of being mindful; of being energised and relaxed. This, I propose, is the space of learning offered by a retreat. Deep pedagogies are helpful for original thought to arise in the complex, varied, prolonged engagement needed for research writing.

In the next section I present the retreat programme which is designed to facilitate such a balance.

\section{RETREAT DESIGN FRAMEWORK}

A retreat takes into account the need for recovery so that energy is restored and focus is regained. (The balance proposed in the wellness quadrant of moving in the positive side between high energy and low.) A retreat may be a site of freedom as well as contribution to community.

... the professional is seen as an agent who is empowered to define her own conditions of work; who has agency to construct her own meaning and identity. (Quinn 2012, 3)

Concurring with Quinn, retreat facilitators trust that writers will set their own goals, keep commitments, and endeavour to meet these. I acknowledge that for academics leisure spaces and work spaces are blurred. With this in mind I aim to create a restorative and generative space that inspires productivity as well as creativity and mindful inquiry. Creativity is encouraged through free-writing and drawing (See Haarhoff 1998; Badenhorst 2007).

By slowing down we see clearly, we let go of preoccupations and find a balance between being energised and relaxed. Mindful pedagogy is premised on our being 'fully present' (Smalley and Winston 2010), being able to relook at both ourselves and the work in hand. The claim for the insights arising through being mindful does not preclude encountering difficulties. 
A retreat space is not necessarily all lovely and peaceful; 'being with what is' often includes exhaustion and confusion. The retreat space allows for recovery through acknowledging that struggles are part of the writing process.

Colleagues also offer support in listening to dilemmas, offering suggestions, or respecting the quiet spaces. I concur with Grant and Knowles (2000) that contributing to the academic discourse is both collaborative and social; the retreat pedagogy is therefore designed to foster peer learning.

A participant offers this reflection on the writing retreat:

On retreat I don't drive through traffic leaving home at 6:15am after a hurried coffee. I don't queue at the security gate. I don't start by dealing with dozens of emails, some phone calls, unexpected requests, meetings, crises, and the sense of rising agitation. Instead I wake up with a view of the mountain, the thoughts of my paper still quietly in my head. We all breakfast together and begin our day with a check-in and some creative activities such as free-writing, drawing, or some writing strategy such as writing an abstract or developing and argument. (Retreatant 39)

This free-write illustrates how the retreat encourages the shift from stress to renewal and to productivity discussed in the wellness model (Figure 1). As both facilitator and writer on retreat I find that knowing that the whole group is writing helps me keep focussed; knowing that I will read to the group helps me stay motivated. This view is confirmed by Badenhorst et al. (2015, 4): '... writing reflections and sharing them with the group was essential in helping members learn the professional practices of becoming an academic'. Writing in a quiet room all together has a special energy; writing alone in a comfortable space away from distractions lets me relax into a sense of ease and timelessness. The inner space reflecting the outer space: it occurs to me that this is one example of re-imagining of spaces for developing teaching and learning (Quinn 2012).

I have put forward arguments for acknowledging staff stress and the need to promote wellness, for the appropriateness of mindfulness and creativity as retreat pedagogy. These arguments arise from an iterative process of reflection, experience of running writing retreats, and from retreating myself for longish periods on silent meditative retreats.

As a way of illustrating the iterative process of retreat design, and my theoretical reflection I turn now to retreatants' responses from mostly residential retreats run from 2012-2016. I inductively synthesised 80 response sheets which resulted in producing six main themes. I include examples of responses: one from evaluation forms and the second from free-writes. After each I engage in a brief discussion. 


\section{RETREATANTS' RESPONSES 1}

The following comments from participants of their experiences of the retreat space were first coded and then grouped into six dominant emerging themes. Below are indicative quotes.

\section{Clarity / insight: (Relating to mindful inquiry)}

- The space afforded me to clear my mind and work at my own rhythms and pace ...

- Put my thoughts together in a more coherent form.

- I am feeling light and free. That I am not bound by the constant shackles of my mind.

- It is just about making things clearer.

\section{Creativity:}

- I have learned new, and reinforced existing approaches to being creative and adventurous and rigorous in my writing.

- Creative, supportive safe place in which to grow ...

- The freedom has its own way of enhancing creativity.

\section{Productivity / motivation:}

- Established healthier approaches to my work.

- Delighted with the progress on my paper - breaking through numerous barriers.

- Did a great deal of thinking and writing.

- It is remarkable how much can be accomplished in this kind of retreat.

- I am seeing myself as an 'I can do' person.

- Short term goal - I have completed my first draft by Friday. Process goal - I write from a place of authenticity in an academic framework. I achieved both goals!

\section{Confidence:}

- I have confidence that I can 'get unstuck'.

- Reading? Initially it was hard, not really easy when you believe that what you write may be a load of hogwash ...

- I overcame blocks and did a great deal of thinking and writing.

\section{Collegiality:}

- I got very valuable input from colleagues.

- At the end I loved the sharing, learning and freedom it brought.

- I enjoyed the support and interest of fellow writers.

- Collegiality and focus forced me to continue.

- Excellent fostering of collegial and supportive critical dialogue.

\section{Care:}

- I felt well looked after, safe.

- Felt nurtured and cared for.

- ... very safe and encouraging space. 


\section{DISCUSSION 1}

The last two themes: Collegiality and Care are also part of the ethos of mindfulness. Developing empathy for each other and a sense of friendliness is helped through spending time together in a sacred space, that is a space set aside for a mutually supportive focus, a space for what Dirkx's (1997) calls 'soul work'.

I present a separate section on the free-write responses.

RETREATANTS' RESPONSES 2 (reflections on reading one's work to the group):

The following are examples of free-writes in response to the prompt: 'Reading to the group ...'

The reading takes me out of my own head. What seems very clear to me provokes sometimes unexpected comments that indicate things that need dis-embedding or wider reflection. Sometimes it is just about making things clearer - just clarifying something. Often it means having to get rid of stuff and focus on one clear message when I have too many competing for space. (Retreatant 14).

Reading has made me hear my voice, get over the complication that what is made public must be perfect. What hearing other reading has given me is a joy of being an academic and the appreciation of working with thoughtful, clever people who want to make a contribution to the world and who are brave enough to share still-to-be polished ideas and drafts. (Retreatant 18).

It was hard ... But on the other hand it did provide a space, a safe space, to get advice from colleagues to learn. At the end I loved the sharing, learning and freedom it all brought: no judgement, constructive and valuable criticism. (Retreatant 33).

'The reading feedback has given me both a sense of accomplishment and critical signposts as to where I can strengthen my ideas; my arguments make my writing clearer. The accomplishment comes from having something worth reading that sounds like an unleashing set of ideas. It is a sensory experience to read aloud and to acknowledge the depth of what already is taking place. The feedback gives me those critical but sensitive ears listening to my ideas and being able to see/hear something I was not aware of: assumptions, logic and argument, inadequate links or whatever ... (Retreatant 4).

\section{DISCUSSION 2}

These typical responses are consonant with the themes drawn out from the evaluations. They also show how some writers start out with some reluctance to read their work but appreciate receiving feedback and listening to the work of others. As Moore (2003), and Lee and Boud (2003) noted, motivation increases through peer support, as well as working in a community of research practice (Murray 2012).

Free writing is shared in a quiet listening space that is mostly appreciative, often profound, and sometimes light-hearted. Free writes connect us to being present and by definition require the suspension of the internal editor and critic: 
I sit down to write.

Time gets lost in the rose bush.

Words drop onto the page. (Retreatant 10).

Some of these writing samples that are read out in the morning sessions are unconnected to a research paper or chapter but are simply a freeing-up of writing and are designed to bring us into a moment of connection and of openness in reading out to colleagues unedited thoughts. Reading free writes, unrevised, personal, sometimes silly, sometimes revealing, possibly incoherent, often amusing, fosters a sense of trust in the group. Experiencing trust helps us to take risks and reduces feelings of pressure (Pryce-Jones 2010).

Such sharing of writing brings us together and opens up a space for reflecting and connecting. Reading one's free-writing also makes it easier to read out drafts of a journal article. There is a developing sense of safety and of 'work-in-progress'. That papers go through numerous iterations is a surprisingly hidden - although obvious - aspect of writing. Novice writers especially are used to reading only published papers (rather than reviewing articles or students' work), and often feel that their drafts are nowhere ready to be revealed to others. In a supportive space reading aloud becomes easier, and writers learn to hear different voices, to see writing taking shape and are able to contribute to the coherence of each other's writing.

\section{CONCLUDING}

While much has been written about the structure of writing retreats, their outcomes and benefits, there has been an absence of inquiry into the 'retreat' aspect. This article unfolds the underlying premise of what it means to retreat; how recovering from stress is a necessary prerequisite to being productive. Field $(2009,13)$ argues for an iterative cycle: 'it seems reasonable to hope and expect that learning will increase well-being, and equally that a sense of well-being is likely to promote confident and effective learning ...'. The iterative cycle is evident in the process of 'quiet writing pedagogy' argued for here where the retreat is designed to span a space between productive flow and renewal. This space is one of creativity and mindful inquiry. The traditional contemplative retreat of withdrawal, as well as collective practice, is ideal for stretching ourselves in writing beyond our boundaries. The outer peaceful retreat setting reminds one of a space of inner peace and spaciousness where creativity arises more freely, and effort is effortless.

Encouraging mindfulness through retreat-as-pedagogy enables new insights, creativity, motivation, confidence, as well as collegiality and care. Participants identified aspects of retreating that contributed to their learning about writing, and actually writing: opportunities 
for participating in a community of trust; nurturing spaces; and withdrawal from daily demands. In designing a retreat in the tradition of mindful inquiry I argue that the retreat itself is the pedagogy for research writing.

\section{ACKNOWLEDGEMENTS}

I would like to acknowledge my colleague, Prof. Jane Castle, with whom I have designed and run numerous research writing retreats.

This article is written with the support of funding from the DHET NCTDG Project: The improvement of teaching and learning in South African universities through researching and evaluating TDG projects in the First Year Experience (FYE) initiatives, Tutorials, Mentoring and Writing Retreats.

\section{NOTES}

1. The Science of Happiness EdX (GG101x) (EdX Course)

2. https://courses.edx.org/courses/course-v1:BerkeleyX+GG101x+3T2016/info http://oxfordmindfulness.org

\section{REFERENCES}

Antoniou, M. and J. Moriarty. 2008. What can academic writers learn from creative writers? Developing guidance and support for lecturers in Higher Education. Teaching in Higher Education 13(2): 157167.

Ashwin, P. 2015. Reflective teaching in higher education. London: Bloomsbury.

Badenhorst, C. 2007. Research writing: Breaking the boundaries. Pretoria: Van Schaik.

Badenhorst, C. M., R. Joy, S. Penney, S. Pickett, J. Hesson, G. Young, H. McLeod, D. Vaandering and X. Li. 2015. Becoming an academic: Reflective writing and professional development. In Writing for professional development, ed. G. Ortoleva, M. Betrancourt, P. Tynjälä and S. T. Billett. Leiden, The Netherlands: Brill Publishers.

Bentz, V. M. and J. J. Shapiro. 1998. Mindful inquiry in social research. New York: Sage Publications. Cameron, J. 2006. The artist's way workbook. New York: Jeremy P. Tarcher / Penguin.

Castle, J. and M. Keane. 2016. It was an oasis in a busy life, a busy city: The Centre for Learning, Teaching and Development writing retreat. Journal of Education 16: 207-225.

Centre for Learning Teaching and Development. 2012. Internal report: Survey of staff wellness. University of X, South Africa.

CLTD see Centre for Learning Teaching and Development.

De Bono, E. 1995. Serious creativity. The Journal for Quality and Participation 18(5): 12-18.

Dirkx, J. M. 1997. Nurturing soul in adult learning. In Transformative learning in action, ed. P. Cranton. San Francisco: Jossey-Bass.

Devlin, M. and A. Radloff. 2014. A structured writing programme for staff: Facilitating knowledge, skills, confidence and publishing outcomes. Journal of Further and Higher Education 38(2): 230248.

Fensham, P. 2004. Defining an identity: The evolution of science education as a field of research. 
Dordrecht: Kluwer Academic Publishers.

Field, J. 2009. Well-being and happiness. Inquiry into the future of life-long learning, 1-52. England and Wales: National Institute of Adult Continuing Education.

Goman, C. K. 1989. Creativity in business, a practical guide for creative thinking. California: Crisp Publications Inc.

Grant, B. 2006. Writing in the company of other women: Exceeding the boundaries. Studies in Higher Education 31(4): 483-495.

Grant, B. and K. Knowles. 2000. Flights of imagination: Academic women be(com)ing writers. The International Journal for Academic Development 5(1): 6-19.

Gundry L. K. 2007. Managing creativity and innovation in the $21^{\text {st }}$ century. London: Sage.

Haarhoff, D. 1998. The writer's voice: A workbook for writers in Africa. Johannesburg: Zebra Press.

Hanson, J. 2009. Displaced but not replaced: The impact of e-learning on academic identities in higher education. Teaching in Higher Education 14(5): 553-564.

Janks, H. 2012. The discipline and craft of academic writing: Building writing capacity in Institutions of Higher Education. Reading \& Writing 3(1), Art \#25, 9 pages. http://dx.doi.org/ 10.4102/ rw.v3i1.25 (accessed 10 October 2015).

Kabat-Zinn, J. 1994. Wherever you go, there you are: Mindfulness meditation for everyday life. UK: Hachette.

Lee, J. J. 2012. Teaching mindfulness at a public research university. Journal of College \& Character 13(2).

Lee, A. and D. Boud. 2003. Writing groups, change and academic identity: Research development as local practice. Studies in Higher Education 28(2): 187-200.

Mittins, M. 2010. Corporate reputational elements reflected in organisational storytelling. Unpublished MBA Research Report. Johannesburg: University of the Witwatersrand.

Moore, S. 2003. Writing retreats for academics: Exploring the increasing the motivation to write. Journal of Further and Higher Education 27(3): 333-342.

Moore, S., M. Murphy and R. Murray. 2010. Increasing academic output and supporting equality of career opportunities: Can writers' retreats play a role? Journal of Faculty Development 24(3): 2130 .

Murray, R. 2009. Writing for academic journals. $2^{\text {nd }}$ Edition. Maidenhead, UK: Open University Press.

Murray, R. 2012. Developing a community of research practice. British Educational Research Journal 35(5): 783-800.

Nairn, R. 1999. Diamond mind: A psychology of meditation. Boston: Shambhala.

Palmer, J. 2002. Identifying the role of creativity in the strategic process. Unpublished MBA dissertation. Johannesburg: University of the Witwatersrand.

Patton, M. Q. 2002. Qualitative research and evaluation methods. Thousand Oaks: Sage.

Prather, C. W. and L. K. Gundry. 1995. Blueprints for innovation: How creative processes can make you and your company more competitive. AMA Management Briefing, American Management Association, New York.

Pryce-Jones, J. 2010. Happiness at work: Maximizing your psychological capital for success. West Sussex, UK: Wiley and Sons.

Quinn, L. 2012. Understanding resistance: An analysis of discourses in academic staff development. Studies in Higher Education 37(1): 69-83.

Samararatne, G. 2007. The gentle way of Buddhist meditation. Penang: Inward Path Publisher.

Smalley, S. L. and D. Winston. 2010. Fully present: The science, art and practice of mindfulness. Philadelphia, PA: DaCapo Press. 
Succito, A. 2011. Meditation: A way of awakening. Great Gaddesden, England: Amaravati Publications.

Wheatley, M. J. 2006. Leadership and the new science. $3^{\text {rd }}$ Edition. San Francisco: Berrett-Koehler Publishers Inc. 